\title{
A Managerial Guide to Products Liability: A Primer on the Law in the United States
}

\author{
Richard J. Hunter, Jr. (Corresponding Author) \\ Department of Economics and Legal Studies \\ Seton Hall University, South Orange, New Jersey, United States 07079 \\ Telephone: 973-761-9511 \\ E-mail: hunterri@shu.edu \\ Henry J. Amoroso \\ Department of Economics and Legal Studies \\ Seton Hall University, South Orange, New Jersey, United States 07079 \\ E-mail: Henry.Amoroso@shu.edu \\ John H. Shannon \\ Department of Economics and Legal Studies \\ Seton Hall University, South Orange, New Jersey, United States 07079 \\ E-mail: John.Shannon@shu.edu
}

Accepted: April 13, 2012 Published: May 06, 2012

Doi:10.5296/ijld.v2i3.1773 URL: http://dx.doi.org/10.5296/ijld.v2i3.1773

\begin{abstract}
This article provides an overview or primer on the law of products liability in the United States for use in the managerial decision-making process. It focuses on the development of case law under the common law in determining a product defect, types of defects, theories of recovery, and the move to the adoption of the theory of strict liability in products cases. The article is written within the context of the Restatement of the Law of Torts. The article provides useful information to the product manager who is responsible for production decisions in a business organization.
\end{abstract}

Key words: Products Liability, Product Defects, Strict Liability in Tort 


\section{Al Macrothink

\section{An Introduction and Overview}

The area of law termed products liability as it developed is a mixture or a hybrid of both contract law (involving either express or implied promises, found in the law of warranties) and tort law (based upon specific conduct, oftentimes reflected in a negligence standard, or actions based on fraud or misrepresentation). In general terms, products liability refers to the obligations or duties of manufacturers, wholesalers (or other middlemen), or retailers/sellers (as well as other parties) to consumers, purchasers, users, and even "bystanders" when a product is found to be defective. No matter what the theory of liability, the predicate of a suit in products liability is a defective product. This defect can arise from three common sources:

- A manufacturing or production defect - that occurs from a random and a-typical breakdown in the manufacturing process;

- A design defect - that is characteristic of a whole product line (such as the infamous Ford Pinto automobile); or

- A marketing defect - involving inadequate warnings concerning risks or dangers, or inadequate instructions relating to how to properly (or safely) use a product (many cases in the area of a marketing defect involve food, drugs, or more recently, children's toys or car seats).

Under the common law, there were three theories under which a plaintiff could bring a suit for personal injury or property damage caused by a defective product. These theories may be summarized as follows:

\subsection{Negligence}

Negligence requires proof that a product was designed or manufactured in an "unreasonable manner," or that the warnings or directions were inadequate under the circumstances.

Drawbacks to a suit based on the theory of negligence involve the requirement, in many cases, of expert proof (which can be quite expensive); the existence of the doctrine of privity, which made it difficult, if not impossible, to reach a negligent manufacturer with whom an injured plaintiff had not personally dealt, and which at the same time absolved the retailer from liability because the retailer had normally only "passed on the product"- -hence the origin of the common law doctrine of "caveat emptor," translated as "let the buyer beware"; the defense of contributory negligence, which at common law was an absolute bar to recovery by a plaintiff shown to have been even slightly negligent; and the sometimes tortured concept of a "reasonable man," more specifically, reaching a consensus on what would be the standard required of a "reasonable manufacturer" or "reasonable designer" or of a "reasonable plaintiff" or "reasonable defendant" under the circumstances of each case. 


\subsection{Misrepresentation and Fraud}

An action based on the theory of misrepresentation or fraud focuses on proof of a false representation of a material fact (found in words, actions, concealment, or in some cases even silence, where the common law found a positive "duty to speak"), upon which a plaintiff reasonably relied in entering into a contract or agreement. At common law, proof of falsehood was required in order to prove a misrepresentation, and proof of scienter ("the intent to deceive"), arising from either "knowledge of falsity or "reckless disregard of the truth," was a part of the "prima facie" proof required in cases of fraud. Often times, an assertion of "safety" or of a "safe product" formed the basis of an allegation of fraud.

A major drawback to a suit based on fraud or misrepresentation was the common belief or expectation that all sellers would in fact engage in a certain amount of "sales puffing" or exaggeration regarding their products, and the common notion that no matter how careful a manufacturer might be, no one could absolutely guaranty the safety of any product, thus negating the element of reasonable reliance as an element of proof.

\subsection{Warranty Actions}

Warranty actions were essentially based on contract promises, either express or implied. Because warranties arose out of the law of contracts, warranties were subject to disclaimers on the part of a seller and could also be severely limited in their scope.

Warranty actions also were subjected to notice requirements (that is, the injured party had to give the party causing the injury a notice that damage/injury had occurred within a rather limited period of time), and the plaintiff was required to prove reliance on specific words or promises made by a seller.

Warranties under the Uniform Commercial Code (UCC) were only applicable in cases involving the sale of goods, and not in the myriad of other types of transactions that resulted in goods or property reaching the hands of a consumer-most notably leases or bailments. Under the common law, privity of contract between a manufacturer and the consumer/buyer (termed vertical privity) was likewise problematic, although the requirement of vertical privity was later severely limited in the 1916 case of MacPherson v. Buick Motors, Court of Appeals of New York, 111 N.E. 1050 (1916). Under the common law, there was also a rule that limited a manufacturer's liability to the actual purchaser of a product and not to any other parties. This aspect of privity was greatly modified with the decision in Henningsen $v$. Bloomfield Motors, Supreme Court of New Jersey, 161 A.2d 69 (1960), which saw the expansion of liability (horizontal privity) under the warranty of merchantability to persons other than the consumer/buyer. This expansion may be seen in UCC Section 2-318, which significantly expanded the range of potential plaintiffs in a warranty action.

The drawbacks inherent in the three common law forms of action led to the development of the modern and now preferred theory in products liability cases - the creation 
of strict (or absolute) liability in tort. The theory of strict liability focuses exclusively on the existence of a product defect and not on the conduct of the defendant (negligence), or on specific words or promises (warranty/ misrepresentation/ fraud). Strict liability permits an injured party, broadly defined, to sue a manufacturer directly, even in the absence of privity; will permit no disclaimers of the manufacturer's duty; and has obviated the strict requirements of notice under warranty actions (often as short as three months), preferring instead to abide by more generous statute of limitation provisions . Under the UCC, the Statute of Limitations can never be less than 1 year and no more than 5 years under the revisions recently adopted.

\section{Types of Product Defects}

As noted, there are three general sources of a product defect: a manufacturing or production defect; a design defect; and a marketing defect, reflected in issues relating to warnings and labels. Section two discusses the types of defects in detail.

\subsection{Production or Manufacturing Defects}

A production or manufacturing defect exists "if the product differs from a manufacturer's intended result or if the product differs from apparently identical products from the same manufacturer." [A California judge's instruction to a jury regarding the nature of a manufacturing defect based on Section 1202 of the California Civil Jury Instructions....]

There are various formulations concerning the existence of a production or manufacturing defect:

- A product which comes off the assembly line in a substandard condition in comparison with other identical units, called "the deviation from the norm" test-sometimes termed as the Lee Test found in Lee v. Volkswagen of America, Inc., Supreme Court of Oklahoma, 688 P.2d 1283 (1984).

- Manufacturing defects are imperfections that occur in a typically small percentage of products of a given design as a result of the fallibility of the manufacturing process. If there are a large number of individual defects, this will probably be seen as a design defect and not an isolated manufacturing or production defect.

- Products that do not conform to their intended design.

- Products that do not conform to the great majority of manufactured products within the design.

- Products that are misconstructed.

- Defects which result from a mishap in the manufacturing process or from improper workmanship, or because defective materials were used. This iteration has been applied to component parts, assembled by the primary manufacturer.

- Products which do not conform to the manufacturers own specifications. 
In a large majority of manufacturing defect cases, courts use a simple test to determine if a product is defective: the "reasonable expectations of the buyer or consumer."

In Hunt v. Ferguson-Paulus Enterprises, 243 Ore. 546; 415 P.2d 13 (1966), the plaintiff bought a cherry pie from the defendant through a vending machine owned and maintained by the defendant. On biting into the pie one of plaintiff's teeth was broken when it encountered a cherry pit. He brought an action to recover damages for the injury, alleging breach of warranty of fitness of the pie for human consumption. In a trial to the court without a jury the court found for the defendant and plaintiff filed an appeal. The court wrote as follows:

"That a consumer of a piece of cherry pie purchased from a vending machine to be consumed at the time of sale, does not reasonably expect to find a cherry pit in such pie."

"In the consideration of similar cases some of the courts have drawn a distinction between injury caused by spoiled, impure, or contaminated food or food containing a foreign substance, and injury caused by a substance natural to the product sold. In the latter class of cases, these courts hold there is no liability on the part of the dispenser of the food."

The court continued:

"All of the cases are instances in which the food was found not to be reasonably fit for human consumption, either by reason of the presence of a foreign substance, or an impure and noxious condition of the food itself, such as for example, glass, stones, wires or nails in the food served, or tainted, decayed, diseased, or infected meats or vegetables."

“... despite the fact that a chicken bone may occasionally be encountered in a chicken pie, such chicken pie, in the absence of some further defect, is reasonably fit for human consumption. Bones which are natural to the type of meat served cannot legitimately be called a foreign substance, and a consumer who eats meat dishes ought to anticipate and be on his guard against the presence of such bones."

Further, the court noted:

"Certainly no liability would attach to a restaurant keeper for the serving of a T-bone steak, or a beef stew, which contained a bone natural to the type of meat served, or if a fish dish should contain a fish bone, or if a cherry pie should contain a cherry stone - although it be admitted that an ideal cherry pie would be stoneless." 
Other courts have rejected the so-called foreign-natural test in favor of what is known as the "reasonable expectation" test, among them the Supreme Court of Wisconsin, which in Betehia v. Cape Cod Corp., 10 Wis. 2d 323, 103 N.W.2d 64 (1960), held that a person who was injured by a chicken bone in a chicken sandwich served to him in a restaurant, could recover for his injury either for breach of an implied warranty of merchantability or for negligence.

\section{The Betehia court noted:}

"There is a distinction between what a consumer expects to find in a fish stick and in a baked or fried fish, or in a chicken sandwich made from sliced white meat and in roast chicken. The test should be what is reasonably expected by the consumer in the food as served, not what might be natural to the ingredients of that food prior to preparation. What is to be reasonably expected by the consumer is a jury question in most cases; at least, we cannot say as a matter of law that a patron of a restaurant must expect a bone in a chicken sandwich either because chicken bones are occasionally found there or are natural to chicken." 10 Wis. 2 d at 331-332.

In Hunt, however, the court found for the defendant and noted: "In view of the judgment for the defendant, we are not required in this case to make a choice between the two rules. Under the foreign-natural test the plaintiff would be barred from recovery as a matter of law. The reasonable expectation test calls for determination of a question of fact..." The trial court, it appeared, had in fact considered both theories and found for the defendant.

\subsection{Design Defects}

Design defects occur where the design of the product makes the product unreasonably dangerous for its intended purpose. Courts will use industry standards, trade customs or "trade usage," or applicable manufacturing codes in order to determine the existence of a design defect. Design defect cases require expert proof, which must be authenticated, and the expert who offers such testimony must be qualified to give objective testimony or render a professional opinion. (Ford Motor Co. v. Bland, 517 S.W.2d 641 (1974)). This requirement implicates what is called the Daubert Rule and may entail a judge acting as a "judicial gate keeper" in order to assure that any alleged expert testimony meets a basic threshold based on real and not "junk" science. (Daubert v. Merrell Dow Pharmaceuticals, 43 F.2d. 1311 (9 $9^{\text {th }}$ Cir. 1995)).

In general, a product will be judged when it is either manufactured or sold. So-called "state of the art" testimony will be utilized to determine the technology available at the point it is either manufactured or sold. 
In recent years, many courts have also imposed a duty on the part of a manufacturer to recall products which were not necessarily defective when they were designed but which have become defective at a later date, perhaps through obsolescence or the passing of time - especially if there is a substantial risk of harm to a large number of persons and if the change required to make the product safer or substantially more safe would be a minimal one.

Design defect cases recognize the fact that there is a risk involved in the production of many products and then the question is asked: Did the manufacturer take reasonable steps to correct or at least minimize the risk?

In determining the existence of a design defect, courts must necessarily balance the economic interests of the manufacturer against the safety interests of the consumer. Under an interpretation found in the Restatement, courts hold that the proper standard to be applied is as follows:

"A product is defective because of its design and unreasonably dangerous if the reasonable seller, having been made aware of the danger involved, would not sell the product."

In many cases, an inquiry will relate to the cost of any change. Courts will frequently inquire whether or not the hazard, danger, or risk could have been obviated at a slight cost. (For example, selling or manufacturing a lawnmower without a dead man's switch which could have been added or supplied for less than $\$ 5.00$, as seen in Burch v. Sears Roebuck, 320 Pa. Super. 444, 467 A.2d 615 (1983)).

The state of New Jersey provides a statement of the majority view concerning the obligation of the parties in proving a design defect. New Jersey courts require that the plaintiff must prove there is a "practical and technically feasible" alternative design that will not impair the core function of the product or unreasonably increase its cost.

\subsection{Product Warnings}

In general, in order for a warning to be adequate, it must make the product safe for both its intended and foreseeable uses (including any potential foreseeable misuse - especially by children). A warning must also take into account the "environment of use" of a product.

There are three criteria that are used by the courts concerning the adequacy of warnings:

- A warning must be displayed in such a way as to reasonably "catch the attention" of the person expected to use the product. (This element deals with such factual questions as size, position, and even the color of the warnings.) 
- A warning must fairly apprise a reasonable user of the nature and extent of the danger and not minimize any danger.

- A warning must instruct the user as to how to use the product in such a way as to avoid the danger-essentially, how to safely use the product.

Courts emphasize that manufacturers must anticipate reasonable risks and warn of these risks. Manufacturers must also appreciate the "environment of use" of a product - as was determined in Spruill v. Boyle-Midway, Inc., 308 F.2d 79 (4 ${ }^{\text {th }}$ Cir. 1962).

There may be a close relationship between a defect arising as a result of a failure to warn and a defect arising as a result of a defect in the design of a product. In some jurisdictions, the failure to warn may be seen as evidence of a design defect in the product itself because proper instructions and warnings are seen as an integral part of the design of a product itself!

Spruill was decided within the context of "inherently dangerous products" (the issue discussed in Thomas v. Winchester, 6 N.Y 397, 57 Am. Dec. 455 (1852)), where the "danger of injury stems from the product itself, and not from any defect in it" or not resulting from negligence in the course of manufacture. Spruill establishes that the basic test in a product warning case should be "reasonable foreseeability" and that a manufacturer must anticipate the environment which is normal for the use of its product.

The requirement of Spruill that the product must be "inherently dangerous" in order for there to be a duty to warn is no longer the law. A warning is required for any product, which may be considered dangerous if used in its intended fashion as a result of a defect in its design - today encompassing a wide variety of consumer products, food products, and pharmaceuticals.

By focusing on the warnings, the jury may be persuaded that a manufacturer should have changed or modified its warnings rather than change its design. But in either case, the product is defective and liability would follow!

Some important points have been made by courts in discussing issues relating to product warnings:

A warning is not adequate if it minimizes the danger associated with a product, especially if there is a known and documented problem. An example may be seen in the following warning: "Inhalation of asbestos in excessive quantities over long periods of time may be harmful." The Fifth Circuit Court of Appeals held in Borel v. Fireboard Paper Products Corp., 493 F.2d 1076 ( $5^{\text {th }}$ Cir. 1973), that this was not adequate to inform insulation workers of the substantial risk of contracting asbestosis and cancer because of the presence of the word "may" in the warning. 
However, a majority of American courts have ruled that there is no duty to warn about an obvious or generally known danger or where it can be shown that a plaintiff has actual knowledge about the danger associated with the use of a product. This is substantially an "assumption of risk" defense that will be discussed in greater detail in the materials on negligence.

Restatement 402A, Comment $\mathrm{j}$ tracks this point and states: "A seller is not required to warn with regard to products, or ingredients in them, when the danger or potentiality of danger, is generally known and recognized."

In such a case, it is argued that the warning would serve no practical or useful purpose since it would tell the user nothing that he does not already know. Some states, for example, New Jersey, have in the past required that warnings must still be provided (and posted conspicuously) — even relating to obvious dangers - because of overriding public policy considerations which require that the maximum amount of information be given to consumers in all cases.

To whom must the warnings be given? Unless required by an administrative agency or some division of the government, warnings must be given to the user or consumer, but not to the general public, because it might be difficult or impossible to effect or monitor such warnings. Where products are sold to "sophisticated industrial users" for their use in the manufacturing process, the manufacturer or supplier is not required to warn the purchaser's employees. The supplier can escape liability by adequately warning and training the purchaser. This rule would only apply to producer goods, as opposed to consumer goods, which are defined as goods purchased for "personal, family or household use."

Concerning warnings relating to prescription drugs, a manufacturer's duty to warn is limited to an obligation to advise the prescribing physician of any potential dangers that may result from the drug's use. This is called the "learned intermediary" exception. The most frequently cited case is Reyes $v$. Wyeth Laboratories, 498 F.2d 1264 ( $5^{\text {th }}$ Cir. 1974). Manufacturers, thus, have no duty to warn the patient directly. As to nonprescription (over-the-counter) drugs, the manufacturer must warn consumers directly by and through adequate labels, warnings, and directions.

The "learned intermediary" exception has been held not to apply where a prescription drug such as a vaccine is distributed in a mass immunization program in which the drug manufacturer participated, or where a drug is distributed through public health clinics. (Davis v. Wyeth Laboratories, Inc., 399 F.2d 121 (9 ${ }^{\text {th }}$ Cir. 1968). In such a case, the role of the physician is minimal or perhaps practically nonexistent.

There are significant minority views, especially relating to common drugs - most notably some antibiotics and birth control pills - because of their routine use and prescription, and again, because of the limited role of the physician. The FDA now requires 
direct consumer warnings in cases relating to common drugs, but such a position is problematic because of the local nature of product liability suits.

As noted earlier, there is also an issue concerning a possible requirement of a duty to warn after the purchase of a product. A manufacturer may incur liability for failing to warn relating to dangers in the use of a product which come to its attention after manufacture or sale which occur as a result of advancements in the "state of the art," or where the manufacturer has been made aware of dangers in the use of the product.

Whether such a warning must be given may depend on:

- The degree of danger involved;

- The number of instances reported; and

- The cost of any change to the product that might be required in relation to the danger perceived.

\section{Tests of a Product Defect}

How do we know if a product is defective in either design or manufacture? This determination is very complex and no single rule or test will apply uniformly throughout the United States. These are common examples of formulations of tests relating to product defects:

The first is the "consumer expectations test" by which we look to the reasonable expectations of the consumer or purchaser. The test has been formulated as follows:

The article sold must be dangerous to an extent beyond that which would be contemplated by the ordinary consumer who purchases it, with the ordinary knowledge common to the community as to its characteristics.

This is the test discussed in Gray v. Manitowoc Co., Inc., 771 F.2d 866 ( $5^{\text {th }}$ Cir. 1985), which has its basis in Comment I of Section 402A of the Restatement of the Law of Torts.

Dean Prosser, the main author of the Restatement of the Law of Torts, restated the test as follows: Would the ordinary consumer expect to encounter such a risk in using a product? We may note the similarity to the "reasonable man" test formulated in negligence cases, discussed earlier. We may also note the intentional use of the word ordinary as a synonym for the word reasonable.

As noted earlier, defects in products are of two general types: patent or obvious and latent or hidden. Generally, courts apply the consumer expectations test more rigidly where 
a defect is latent because the consumer may be completely unaware of any danger posed by a product and could therefore reasonably expect the product to be safe.

The standard of "consumer expectations" is very close to that of merchantability found in UCC Section 2-314, where in order to be merchantable, goods sold must be "fair, average quality and fit for their ordinary purpose" (as determined by the ordinary or reasonable consumer).

Brawner v. Liberty Industries, Inc., Missouri Court of Appeals, 573 S.W.2d 376 (1978), makes an important point, noting that a manufacturer is not an insurer; that is, a manufacturer does not promise or guaranty that he has created or manufactured a product that is accident-proof or safe under all circumstances. In Brawner, the court held that a product that is made safe for adult use is not necessarily defective and unreasonably dangerous solely because it has not been made childproof. There is no "reasonable expectation" that the product would, in fact, be child proof. However, it should also be remembered that the Spruill court introduced an additional parameter into its discussion-the concept of the "environment of use." If it could be foreseen that the product might or would be used by a child, the application of the "consumer expectations test" might lead to the conclusion that the product was defective.

In Keller v. Welles Department Store of Racine, 88 Wis., 2d 24, 276 N.W.2d 319 (1978), a design defect case, the court noted:

If the average consumer would not reasonably anticipate the dangerous condition of the product and not fully anticipate the attendant risk of injury, it would be unreasonably dangerous and defective.

\subsection{Assumption of Risk Analysis}

If a reasonable consumer knows about a risk and proceeds nevertheless to use a product, it may be said that the consumer has "assumed the risk" of such use.

These are the two traditional elements of the defense of assumption of risk: knowledge of a known risk, and voluntary acceptance of that risk. It appears that the consumer expectations test is but another formulation of the circumstances under which a consumer will assume the risk of using a product. If there were a known risk (a patent or obvious risk), then a reasonable consumer would not have the expectation that the product is completely safe and would be expected to act accordingly.

A problem with the "consumer expectations" test arises in design cases because the product may be too complex to generate any concrete consumer expectations. Consumer expectations about safety are often vague or will oscillate between "it will never happen to me" or "all products are poorly made." There is thus an anomaly that since most consumers 
are highly skeptical about statements made by manufacturers concerning their products, it might never be seen as a "reasonable expectation" that a product is safe!

\subsection{The "Risk-Utility" Test or "Risk-Benefit" Test: A Shift to the Manufacturer}

Many courts have approached the problem from the viewpoint of judging the conduct or inaction on the part of the manufacturer. This test looks to what a reasonable seller/manufacturer would do. It is essentially a negligence standard, based on the expected conduct of a "reasonable manufacturer." This test also has enormous ethical and social responsibility implications. Under a risk-utility analysis, we are asked to determine that the product should never have been marketed or manufactured in the first place!

The "risk-utility" test revolves around a simple concept: Whether the cost of making a safer product is greater than the risk from using the product in its present form. If the cost of making the change is greater than the risk created by not making the change then the utility of keeping the product as is outweighs the risk and the product is not defective. If the cost of making the change is minimal or is less than the risk created by not making the change, then the benefit or utility of keeping the product as is outweighed by the risk and the product is defective. This is obviously a balancing act - a judgment call—on the part of the trier of fact. In many cases, the cost of effecting any change will be the most significant or overriding factor in applying the "risk-benefit/risk-utility" test. The lower the cost, the more likely that a court or jury will find that the product without the change is in fact defective!

The common standards or factors used for determining risk-utility or risk-benefit are found in footnote number 13 in Phillips v. Kimwood Mach. Co, 269 Or. 485, 525 P.2d 1033 (1974):

- The usefulness and desirability of the product: There are some products that have little or no utility and would not even pass this "threshold" test. Such products today might include assault weapons for skeet shooting; some large "home use" fireworks displays; a four foot high backyard swimming pool with a diving board attached; or lawnmowers or pleasure boats without a 'dead mans' switch.

- The likelihood and probable seriousness of injury from the product as it is manufactured.

- The availability of a substitute product that would meet the same needs of the consumer and not be unsafe. If there are no viable substitute products, it might be difficult to find this product defective. Think of this in terms of an experimental drug used to treat cancer or AIDS. Such a drug may be very dangerous but still may have a very high utility.

- The manufacturer's ability to eliminate the danger without impairing the usefulness of the product or making the product too expensive. This is the essence of the standard from the standpoint of the manufacturer! If a product becomes "too expensive," no one would be able to purchase it at all! 
- Given the nature of a danger, the user's ability to avoid the danger (especially with proper warnings, labels, or instructions).

- The user's anticipated awareness of the danger.

- The feasibility of spreading the risk by pricing decisions or through the purchase of insurance.

Phillips makes an important point in the following statement (which, in practical terms, will probably become the standard in such cases):

\section{A dangerously defective article would be one which a reasonable person would not put into the "stream of commerce" if he had knowledge of its harmful characteristics.}

This is a "presumed knowledge" standard under which it must be shown that the manufacturer did in fact know of the danger or harmful characteristics of a product.

As noted, Phillips also suggests that if a change in a product could have been effected at a relatively small price, there is a good chance liability will be imposed for not making the change. This may be the most important consideration for a jury!

In employing the risk-utility test, manufacturers, first, and then courts must balance several factors:

- Product cost: the relative cost both to the manufacturer and the consumer of producing, distributing, and selling the original product as compared to the product with the alternative design.

- Technological feasibility of an alternative design (e.g., a child's crib with larger slats, thus with smaller gaps).

- Time lag required to effect necessary changes or within which to implement the alternative design. The shorter the time period needed to correct a problem, the more likely that a court would require the change to be made.

- The effect the new design has on product performance. Cars that travel at five miles per hour would be much safer but would they be practical or have any utility? Apple pie or coffee served by a fast-food franchiser like McDonald's at room temperature would be much safer but would anyone want to purchase such products?

- Benefits to the economy, in general, in terms of employees hired, benefits to suppliers, taxes paid or generated, charitable activities engaged in by a business, or other intangible benefits to society (for example, the utility of an experimental vaccine during an epidemic).

Cigarette manufacturers have frequently attempted to introduce so-called "beneficial" evidence in cases involving liability and cite to their substantial charitable foundations as evidence of their product's utility or value to society. It might be important to note that in 
New Jersey, Washington and many other states, courts will not permit the introduction of any evidence regarding this assertion.

In applying the risk-utility test, a product may be found defective in design even if it satisfies normal consumer expectations, if through hindsight, the jury determines that the design embodies "excessive preventable danger," or if the risk of danger, inherent in the challenged design, outweighs the benefits of the design.

In Barker v. Lull Engineering Co., 143 Cal. Rptr. 225, 573 P.2d 443 (1978), the court stated that the burden of proof is shifted to the manufacturer, once the plaintiff proves that a design defect caused the injury. Under the risk-utility test, the defendant must then prove that on balance, the benefits of the challenged design outweigh the risk of danger in such a design.

Note that this is contrary to the view that the plaintiff must present evidence of a feasible, alternative, and safer design and places the burden of proof on the defendant-manufacturer. However, this change in the burden of proof seems to be in line with the general philosophy of products liability cases which intentionally places the responsibility on the party best able to pay or absorb this cost. Thus, the Barker case may represent the future trend in products liability cases that places the clear burden on the manufacturer-defendant rather than on the person who suffered injury.

\section{Unavoidably Dangerous Products, Negligence per Se, and Preemption}

There are three special considerations in determining liability in a host of product cases.

\section{1 "Unavoidably Dangerous Products"}

"There are simply some products which, in the present state of human knowledge, are quite incapable of being made safe for their intended and ordinary use... Such a product, properly prepared, and accompanied by proper directions and warnings, is not defective, nor is it unreasonably dangerous. " (Feldman v. Lederle Laboratories, 97 N.J. 429, 479 A.2d 374 (1984), quoting Comment k to the Second Restatement.)

Examples of such products are especially common in the field of drugs, vaccines, blood products, medical devices, and especially new or experimental medications. Recent examples are the host of drugs used in the treatment of AIDS — and perhaps handguns or knives.

In Wilkinson v. Bay Shore Lumber, 182 Cal. App. 812, 227 Cal. Rptr. 327 (1986), the court held that "the few reported decisions which refer to comment $k$ overwhelmingly involve products such as drugs, vaccines, blood, and medical devices such as intrauterine devices and 
breast implants." Thus, there may be immunity from the imposition of strict liability, but not blanket immunity in all cases. The plaintiff can still win a case but must prove some sort of negligence, i.e., in manufacturing, preparation, or warnings, labels or directions.

Comment $\mathrm{k}$ continues:

"The seller of such products... is not to be held to strict liability for unfortunate consequences attending their use, merely because he has undertaken to supply the public with an apparently useful and desirable product, attended with a known but apparently reasonable risk."

\subsection{Effects of Statutes and Administrative Regulations}

Courts may adopt as the standard of conduct of a reasonable man either a statute or an administrative regulation. This raises the stakes considerably in products cases!

In cases involving a statute or an administrative regulation, an unexcused violation is termed negligence per se, and creates a presumption of negligence on the part of the actor that may only be overcome by strong, powerful and conclusive evidence-sometimes called "clear and convincing proof." However, an excused violation would not amount to a finding of negligence per se. The following are accepted examples of excused violations of a statute or regulation: the inability to comply; an emergency situation; or where compliance would involve a greater risk of harm than non-compliance. Courts, however, construe these examples very narrowly.

However, on the other side of the equation, there appears to be a strong anomaly: compliance with a statute or regulation is not necessarily proof that a party acted reasonably and is not a bar to recovery or a finding of negligence if a reasonable man [manufacturer] would take additional reasonable precautions. The statute or regulation is seen as the legally minimum standard, although in most states, compliance with the law or statute would be given a strong presumption - termed as a rebuttable presumption - that a party had acted reasonably under the circumstances. [A rebuttable presumption either of negligence or that a party has not been negligent is a "marker," laid down by a court as a matter of law, but may be countered by "clear and convincing proof or evidence."]

Examples of actions in the area of pharmaceuticals that have resulted in imposition of negligence per se include: failing to follow the proper steps in gaining approval of a drug (following the FDA Protocol, termed the Drug Development and Approval Process); failing to file required health and safety reports; or filing such reports in a non-timely manner. 
5.3 Preemption

There are four aspects of the preemption discussion; that is, deciding whether a specific state regulation would or would not be preempted by federal regulations in the absence of an express preemption clause in the federal legislation:

- Congress may intend to "occupy the field" in a given area because federal regulations may be so pervasive or the federal interest so dominant, as in federal labor legislation or in issues relating to nuclear waste disposal (Silkwood v. Kerr-McGee Corp., 464 U.S. 238 (1984).

- Where a state law or statute conflicts with a federal rule.

- Where a state law or statute stands as an "obstacle" to the accomplishment and execution of the purposes of Congress.

- Where it would be a physical impossibility to comply with both federal and state law.

In such cases, state regulations or causes of action based upon state remedies would be preempted. In Cipollone v. Liggett Group, Inc., 505 U.S. 504 (1992), which is important as well from an historical point of view - outlining the history of the required warnings on cigarette packages and the evolving form of the warning itself so as not to minimize the danger of smoking - the United States Supreme Court held that federal law preempts only those actions that related to the required warnings, advertising, or promotion of cigarettes. Other actions or theories of recover offered by the plaintiffs, with the exception of those based on the required warnings, were not preempted and could proceed to trial.

\section{Creation of Strict Liability as the Preferred Theory in Product Cases}

In Greenman v. Yuba Power, 27 Cal. Rept. 697, 377 P. 2d 897 (1963), Justice Traynor laid out the basis for the imposition of strict liability in modern product liability cases:

"A manufacturer is strictly liable in tort when an article he places on the market, knowing that it to be used without inspection for defects, proves to have a defect that causes injury to a human being."

"Although...strict liability has usually been based on the theory of an express or implied warranty running from the manufacturer to the plaintiff, the abandonment of the requirement between them, the recognition that the liability is not assumed by agreement but imposed by law... and the refusal to permit the manufacturer to define the scope of his own responsibility for defective products...make clear that the liability is not one governed by the law of contract warranties but by the law of strict liability in tort."

"The purpose of such liability is to insure that the costs of injuries resulting from defective products are borne by the manufacturers that put such products 
on the market rather than by the injured persons who are powerless to protect themselves."

"To establish the manufacturer's liability it was sufficient that plaintiff proved that he was injured while using the Shopsmith in a way it was intended to be used as a result of a defect in design and manufacture of which plaintiff was not aware that made the Shopsmith unsafe for its intended use."

\subsection{The Historical Development of the Theory of Strict Liability in Tort}

Before Greenman, a plaintiff in a products liability case had to rely on the theories of negligence, breach of warranty, or misrepresentation or fraud for recovery. These theories were not specific to products cases and presented plaintiffs with certain formidable "obstacles" described in Part 1 of this article.

In 1944, in Escola v. Coca Cola Bottling, 24 Cal. 2d 453, 150 P.2d. 436 (1944), a res ipsa loquitur case, Justice Traynor argued in his concurring opinion that these traditional theories were inadequate and that the court should adopt a new and special theory for product cases. "In my opinion, it should now be recognized that a manufacturer incurs an absolute liability when an article he has placed on the market, knowing that it is to be used without inspection, proves to have a defect that causes injury to human beings." The privity requirement, however, rendered most common law forms of recovery based on negligence or warranty inadequate the remedy inadequate because most consumers could not at that pre-Henningsen time (1960) sue the manufacturer of the harmful product because they were not in privity of contract with the manufacturer. Their contract was with the retailer.

In 1965, the American Law Institute embraced the Greenman principle in Section 402A of the Restatement (Second) of Torts.

"1. One who sells any product in a defective condition unreasonably dangerous to the user or consumer or to his property is subject to liability for physical harm thereby caused to the ultimate user or consumer, or to his property, if

a. The seller is engaged in the business of selling such a product, and

$b$. Is expected to and does reach the user or consumer without substantial change in the condition in which it is sold.

2. The rule applies although:

a. $\quad$ The seller has exercised all possible care in the preparation and sale of his product, and

b. The user or consumer has not bought the product from or entered into any contractual relation with the seller." 
What is apparent that the philosophy articulated by Justice Traynor in the Greenman decision has been followed in the Restatement version of the strict liability standard. Subsection (2) is clearly intended to place responsibility for safe products on the seller or manufacturer rather than an unknowing user or consumer. Further, Section 402A continues to remove the requirement of proof of fault as did Greenman. However, Section 402A adds the condition that the product be unreasonably dangerous to the Greenman standard. This addition has generated some significant controversy. This has led a variety of jurisdictions to adopt the Greenman standard rather than purely Section 402A. Barker v. Lull Engineering, discussed earlier, is illustrative of this disagreement.

The Greenman decision, coupled with Section 402A (originally thought to apply only to food and drink cases), has certainly provided the "intellectual basis" for the transition from warranty to strict liability in tort and represented the beginning of modern products liability law. A great many developments have taken place since 1965 and, as a result, many courts have departed substantially from the original Restatement rule. Each state is free to interpret Section 402A and to expand this important concept on a case-by-case basis.

As a general rule, the basic elements of strict products liability cases may be expressed as follows:

- The defendant is in the business of producing or selling the product [status as a merchant];

- The product was expected to and did reach the purchaser without substantial change in the condition in which it was sold;

- The product was defective [in design, manufacture, or warnings] when it left the defendant's control;

- The harm resulted when the product was being used in a reasonable foreseeable manner;

- The person harmed was "foreseeable"; and

- The defect was the cause in fact and proximate cause [legal cause] of physical harm to the plaintiff's person or property.

\subsection{Policies Underlying Strict Liability:}

Courts, commentators, and scholars have advanced a variety of "policy justifications" for the imposition of strict tort liability. (Fischer \& Powers, pp. 50-51 (1988)). The following are the most prevalent and are summarized briefly:

- Loss Spreading: It is both humane and fair to shift losses from an individual to all buyers of a product by imposing strict liability on manufacturers, thus forcing manufacturers to insure against losses or to spread potential losses among all purchasers through appropriate pricing policies. 
- Deterrence/Incentive: Imposing strict liability on manufacturers provides them with an incentive to market safer products. Strict liability induces manufacturers to go beyond traditional negligence standards of a "reasonable manufacturer," especially if the cost of the added safety measures is less than the potential cost of liability for failure to take them (cost/benefit, risk/utility analysis) — most especially if the cost of any change or modification is truly minimal.

- Encouraging Useful Conduct: Strict liability, based upon reasonable concepts of risk/utility (recognizing that there is some risk in all areas of human activity), will still encourage manufacturers to produce useful products. At its core, a plaintiff will not be compensated simply because he has been injured; rather, a plaintiff will still need to prove that a defect exists, thus holding out to the manufacturer that proper conduct will not be punished.

- Proof Problems: Modern complexities in manufacturing make it very difficult to establish negligence, especially since the manufacturer is usually at a relative advantage in terms of access to expertise, information, and resources. Strict liability frequently will eliminate a plaintiff's need to prove a particular element of a case, such as the existence of negligence, or may eliminate proof of identity of a defendant through the imposition of enterprise liability, Burnside v. Abbott Laboratories, 505 A.2d 973 (1985), or by imposing liability on successor or predecessor corporations. (Bernard v. Kee Manufacturing Co., Inc., 409 So. 2d 1047 (1972)).

- Protection of consumer expectations: Since modern advertising and marketing techniques induce consumers to rely on manufacturers to provide them with safe, high-quality products, consumers should come to expect protection from unknown dangers in products, best exemplified through the imposition of strict liability.

- Cost Internalization: Forcing manufacturers to compensate victims of defective products through the purchase of appropriate products liability insurance or by making an enlightened decision to essentially "self insure" will lead to a more efficient allocation of resources and pricing of products to include all of their true costs, including the costs associated with damages caused by defective products. If funds are readily available from which injured parties can be compensated, manufacturers will be more apt to admit liability rather than "stonewall" in handling complaints of product defects or to change the design of a defective product.

\section{Some Brief Conclusions}

Today, courts are continuing to work out the details of strict liability, by addressing such issues as defenses (misuse, contributory negligence, assumption of risk, etc.) causation, scope of duty, and the applicability and extension of strict tort liability to particular products, sellers, and situations - even permitting a "bystander" to recover under certain circumstances. (Gnirk v. Ford Motor Co., 572 F. Supp. 1201 (1983)).

What is apparent is that courts, in general, have rejected the former notion under the doctrine of privity that manufacturers should bear little or no responsibility for defective 


\section{Macrothink

products and now focus on the product itself and not on outmoded, convoluted or archaic rules which often placed injured consumers at the mercy of manufacturers who placed dangerous and defective products on the market. 


\section{References}

Barker v. Lull Engineering Co., Supreme Court of California, 143 Cal. Rptr. 225, 573 P.2d 443 (1978)

Bernard v. Kee Manufacturing Co., Inc., Supreme Court of Florida, 409 So. 2d 1047 (1972).

Betehia v. Cape Cod Corp., Supreme Court of Wisconsin, 101 Wis. 2d 323, 103 N.W.2d 64 (1960)

Borel v. Fireboard Paper Products Corp., United States Court of Appeals, 493 F.2d 1076 (5 $5^{\text {th }}$ Cir. 1973).

Brawner v. Liberty Industries, Inc., Missouri Court of Appeals, 573 S.W.2d 376 (1978)

Burch v. Sears Roebuck, Superior Court of Pennsylvania, 320 Pa. Super. 444, 467 A.2d 615 (1983)

Burnside v. Abbott Laboratories, Superior Court of Pennsylvania, 505 A.2d 973 (1985)

Cipollone v. Liggett Group, Inc., United States Supreme Court, 505 U.S. 504 (1992)

Daubert v. Merrell Dow Pharmaceuticals, United States Court of Appeals, 43 F.2d. $1311\left(9^{\text {th }}\right.$ Cir. 1995)

Davis v. Wyeth Laboratories, Inc., United States Court of Appeals, 399 F.2d $121\left(9^{\text {th }}\right.$ Cir. 1968)

Escola v. Coca Cola Bottling, Supreme Court of California, 24 Cal. 2d 453, 150 P.2d. 436 (1944)

Feldman v. Lederle Laboratories, Supreme Court of New Jersey, 97 N.J. 429, 479 A.2d 374 (1984)

Fisher, David A. \& Powers, William. (1988). Products liability: cases and materials. $\quad$ St. Paul, Minn.: West Publishing Co.

Ford Motor Co. v. Bland, Court of Civil Appeals of Texas, Waco, 517 S.W.2d 641 (1974)

Gnirk v. Ford Motor Co., United States District Court for the District of South Dakota, 572 F. Supp. 1201 (1983)

Gray v. Manitowoc Co., Inc., United States Court of Appeals, 771 F.2d 866 (5 ${ }^{\text {th }}$ Cir. 1985) 
Greenman v. Yuba Power, Supreme Court of California, 27 Cal. Rept. 697, 377 P. 2d 897 (1963)

Henningsen v. Bloomfield Motors, Supreme Court of New Jersey, 161 A.2d 69 (1960)

Hunt v. Ferguson-Paulus Enterprises, Supreme Court of Oregon, 243 Ore. 546; 415 P.2d 13 (1966)

Keller v. Welles Department Store of Racine, Court of Appeals of Wisconsin, 88 Wis., 2d 24, 276 N.W.2d 319 (1978)

Lee v. Volkswagen of America, Inc., Supreme Court of Oklahoma, 688 P.2d 1283 (1984)

MacPherson v. Buick Motors, Court of Appeals of New York, 111 N.E. 1050 (1916).

Phillips v. Kimwood Mach. Co., Supreme Court of Oregon, 269 Or. 485, 525 P.2d 1033 (1974)

Reyes v. Wyeth Laboratories, United States Court of Appeals, 498 F.2d 1264 (5 ${ }^{\text {th }}$ Cir. 1974)

Silkwood v. Kerr-McGee Corp., United States Supreme Court, 464 U.S. 238 (1984)

Spruill v. Boyle-Midway, Inc., United States Court of Appeals, 308 F.2d 79 (4 ${ }^{\text {th }}$ Cir. 1962)

Thomas v. Winchester, Court of Appeals of New York, 6 N.Y 397, 57 Am. Dec. 455 (1852)

Wilkinson v. Bay Shore Lumber, Court of Appeals of California, 182 Cal. App. 812, 227 Cal. Rptr. 327 (1986)

\section{GLOSSARY}

Enterprise Liability: (1) The injury causing product was manufactured by one of a small number of defendants in an industry; (2) the defendant had joint knowledge of the risks inherent in the product and possessed a joint capacity to reduce those risks; and (3) each of them failed to take steps to reduce the risk but rather, designated this responsibility to a trade association. (Burnside v. Abbott Laboratories, 505 A.2d 973, 984 (1985)).

Res Ipsa Loquitur: Res ipsa loquitur is a Latin term meaning "the thing speaks for itself." The traditional elements needed to prove negligence through the doctrine of res ipsa loquitur include:

1. The harm would not ordinarily have occurred without someone's negligence 


\section{Macrothink Institute ${ }^{\mathrm{TM}}$}

2. The instrumentality of the harm was under the exclusive control of the defendant at the time of the likely negligent act

3. The plaintiff did not contribute to the harm by his own negligence. 